\title{
Use of natural and created Spartina alterniflora salt marshes by fishery species and other aquatic fauna in Galveston Bay, Texas, USA
}

\author{
Thomas J. Minello ${ }^{1, *}$, James W. Webb, $\mathrm{Jr}^{2}$ \\ ${ }^{1}$ National Marine Fisheries Service, Southeast Fisheries Science Center, Galveston Laboratory, 4700 Avenue U. \\ Galveston, Texas 77551, USA \\ ${ }^{2}$ Texas A\&M University at Galveston, Department of Marine Biology, PO Box 1675, Galveston, Texas 77553, USA
}

\begin{abstract}
We compared densities of nekton and infauna among 5 natural and 10 created ( 3 to 15 yr in age) salt marshes in the Galveston Bay system of Texas to test whether these marshes were functionally equivalent. Decapod crustaceans dominated the nekton on the marsh surface during both the spring and the fall. Densities of daggerblade grass shrimp Palaemonetes pugio, the most abundant decapod, were not significantly different among marshes, but the size of these shrimp in created marshes was significantly smaller than in natural marshes. Densities of the marsh grass shrimp Palaemonetes vulgans and of 3 commercially-important crustaceans (white shrimp Penaeus setiferus, brown shrimp Penaeus aztecus, and blue crab Calinectes sapidus) were significantly lower in created marshes than in natural marshes. Gulf menhaden Brevoortia patronus were the most abundant fish collected, mainly on nonvegetated bottom adjacent to marsh habitats. Fish densities within vegetation (predominantly gobles and pinfish Lagodon rhomboldes) were significantly lower in created marshes than in natural marshes. Natural and created marshes, however, did not differ in species richness of nekton. Sediment macro-organic matter and density and species richness of macroinfauna (mainly polychaete worms) were all significantly lower in created marshes than natural marshes. There was a positive relationship in created marshes between marsh age and sediment macro-organic matter, but marsh age was not related to nekton densities. Natural marshes were similar in having low elevations and flooding durations between 74 and $80 \%$ of the year; while created marshes were flooded from 43 to $91 \%$ of the time. In contrast to marsh age, tidal flooding was often related to nekton densities in marsh habitats. We conclude that marsh elevation and tidal flooding are key characteristics affecting use by nekton and should be considered in marsh construction projects.
\end{abstract}

KEY WORDS: Salt marsh - Habitat value Habitat creation - Restoration - Nekton F Fishery species

\section{INTRODUCTION}

The northern Gulf of Mexico is characterized by vast expanses of estuarine wetlands and some of the most productive fisheries in the USA. Fishery productivity is closely linked to these wetlands, and both correlative (Turner 1977, Zimmerman \& Minello 1984, Rozas \& Reed 1993, Peterson \& Turner 1994) and experimental (Minello \& Zimmerman 1983, Minello et al. 1989. Thomas 1989, Minello \& Zimmerman 1991, Heck \&

·E-mail: tom.mineilo@noaa.gov
Coen 1995) evidence indicates that many fishery species in the region depend upon coastal marshes for critical nursery functions such as provision of food for growth and protection from predators. Wetland loss in the region has encouraged efforts to restore salt marshes by planting smooth cordgrass Spartina alterniflora on eroding shorelines, graded-down uplands, or on deposits of dredged material. Although techniques are available for successfully establishing stands of this vegetation under various coastal conditions (Woodhouse et al. 1972, Broome et al. 1988, Broome 1989), the relative value of these created 
marshes for estuarine animals in relation to natural marshes is still a matter of controversy (Race \& Christie 1982, LaSalle et al. 1991, Moy \& Levin 1991, Simenstad \& Thom 1996, Zedler 1996).

Created salt marshes are generally similar to natural marshes in physical appearance. Indeed, these marshes often appear more productive than natural marshes on the basis of above-ground plant biomass (Webb \& Newling 1985, Broome 1989). However, accumulating evidence suggests that natural and created marshes are not functionally equivalent for nekton and other estuarine organisms (Moy \& Levin 1991, Minello \& Zimmerman 1992, Meyer et al. 1993, Zedler 1993, Havens et al. 1995, Zedler 1996). Therefore, replacement of natural marshes with created marshes may result in losses of estuarine and fishery productivity. We need better documentation of functional differences between these marsh types to assess the magnitude of these losses. In addition, if we assume that created marshes can eventually reach functional equivalence with natural marshes, we need information on the optimal conditions and projected time required for this development.

The objective of this study was to compare the relative value of created and natural salt marshes for nekton in the Galveston Bay system of Texas. We assumed marsh use was an indicator of habitat value and measured nekton densities in marshes with an enclosure device (Zimmerman et al. 1984). Five natural marshes were compared with 10 created marshes, ranging in age from 3 to $15 \mathrm{yr}$. We expected this age range to allow an assessment of functional development rate in created marshes. In association with nekton densities, we measured sediment macro-organic matter and the abundance of benthic infaunal organisms available as prey to nektonic predators. We also examined tidal flooding duration as a possible factor governing nekton use of the marshes.

\section{METHODS}

Study area. The Galveston Bay system is the largest estuary in Texas $\left(1420 \mathrm{~km}^{2}\right)$. Spartina alterniflora is the dominant shoreline vegetation in the bay, and the young of many fishery species have been shown to directly utilize this intertidal habitat (Zimmerman \& Minello 1984, Thomas et al. 1990). Due to coastal development, erosion, and subsidence, 19 to $20 \%$ of emergent marshes were lost in the bay system between 1950 and 1989 (White et al. 1993, White \& Tremblay 1995).

Selection of marshes. We identified 10 created marshes that ranged in age from 3 to $15 \mathrm{yr}$ at the time of sampling; substratum type and construction technique also differed among some marshes (Table 1). More detailed physical descriptions of the marshes are available in Delaney (1994). All marshes were distinct entities and separated by at least $0.5 \mathrm{~km}$ of nonvegetated shoreline. The created marshes were located along shorelines of channels, lakes, coves, or the open bay (Fig 1), and the distance of shoreline covered by these marshes ranged approximately from 50 to $700 \mathrm{~m}$. We selected natural marshes that were also located along shorelines, and the length of shoreline sampled for all marshes was less than $700 \mathrm{~m}$. Natural marshes included 2 relatively large marshes, one at Jamaica Beach in West Bay (NA) and one at Peppergrove Cove on Bolivar Peninsula in East Bay (N1); these marshes have been described in previous studies (Zimmerman \& Minello 1984, Webb \& Newling 1985). We also included natural marshes along the Lake Como Channel (N3) and along the shoreline of Halls Lake (N5) because of their proximity to the created marshes $\mathrm{T} 1$ \& T2. The Bolivar Shoreline marsh (N2) was on an exposed shoreline in East Bay and was selected because the high-energy conditions here were similar to those at transplanted marshes on Bolivar (T6, T7, T8, \& T9).

Table 1. Basıc information about created marshes used in this study. Creation technique: PL, planted; NR, naturally revegetated; substrate: DM, dredged material; NS, natural shoreline; GU; graded-down upland; age: marsh age in years at the time of sampling in 1990; location: center of marsh shoreline measured with a Global Positioning System receiver

\begin{tabular}{|lccccc|}
\hline Created marsh & $\begin{array}{c}\text { Creation } \\
\text { technque }\end{array}$ & Substrate & Area (ha) & Age & Location \\
Longitude (W)
\end{tabular}


Fig. 1. Locations of natural (N1 to N5) and created (T1 to T10) Spartina alterniflora salt marshes in the Galveston Bay system of Texas. Locations of tide gauges (TG) are also shown

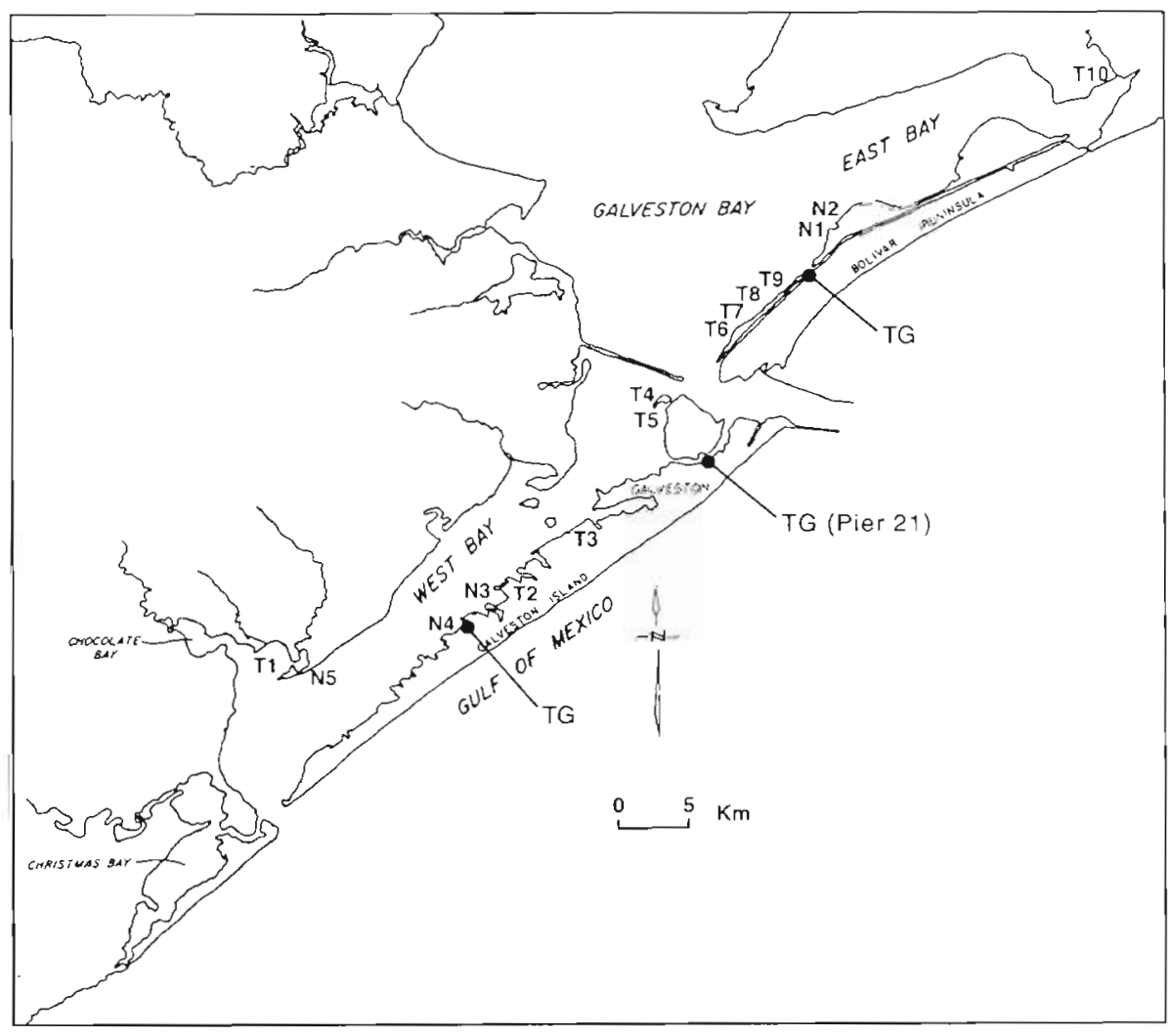

Habitats within each marsh. In each marsh, we collected nekton within 3 habitats: (1) the marsh edge (within Spartina alterniflora about $1 \mathrm{~m}$ from the marsh/ water interface), (2) the inner marsh (about $5 \mathrm{~m}$ into the marsh), and (3) in subtidal habitat (the shallow nonvegetated bottom adjacent to the marsh). Inner marsh is a relative term, and others may consider it a misnomer for marsh habitat only $5 \mathrm{~m}$ from the open water. However, in many of the highly reticulated natural marshes of the lower bay, vegetation occurs as islands less than $10 \mathrm{~m}$ across; thus samples cannot be taken further than $5 \mathrm{~m}$ from a marsh/water interface. In addition, many of the created marshes in this study are narrow strips of vegetation fringing the shoreline, and some (such as the marsh at Palm Beach, T3) are not much wider than $5 \mathrm{~m}$.

Sampling. We sampled nekton in fall 1990 (September 24 to 28) and spring 1991 (May 13 to 17). The T7 marsh was covered with dredged material from the Intracoastal Waterway between our sampling periods and was not sampled in spring 1991. The T6 \& T8 marshes also were impacted by the dredging operation, and a thin layer $(5$ to $10 \mathrm{~cm}$ ) of sediment was deposited over portions of these marshes. We restricted the collection of spring samples in these marshes to areas that did not appear to have any newly deposited sediment.

We estimated nekton densities using a drop sampling technique with a $1.8 \mathrm{~m}$ diameter cylinder as described by Zimmerman et al. (1984). We collected 6 drop samples (2 randomly located in each habitat) in each marsh during daylight hours at high tide. We dropped the sampler from a boom on the bow of a skiff and pushed it into the substrate to make a watertight seal. Once the sampler was in place, we measured temperature, salinity, turbidity, dissolved oxygen, and water depth as described by Minello \& Zimmerman (1992). Vegetation in a sample was clipped at the marsh surface and removed to facilitate the collection of animals. We used dip nets to remove most enclosed fauna in the $2.6 \mathrm{~m}^{2}$ sampler and then pumped water from the sampler through a $1 \mathrm{~mm}$ mesh plankton net. Animals were preserved in the field in $10 \%$ formalin with Rose Bengal stain.

We also collected a sediment core $110 \mathrm{~cm}$ diameter, $5 \mathrm{~cm}$ deep) from within each drop sample to estimate the density of benthic infauna and epifauna. The core was taken near the center of the sampler (between clumps of Spartina alterniflora in vegetated habitats) before the sediments were disturbed with dip nets. We washed the upper $5 \mathrm{~cm}$ of sediment through a $0.5 \mathrm{~mm}$ mesh sieve in the field and preserved animals and plant material (roots and detritus) in 10\% formalin with Rose Bengal stain.

In the laboratory, we identified all fishes, crustaceans, and molluscs from drop samples. We measured total lengths for fishes and crustaceans (cara- 
pace width for crabs) and recorded length data in $5 \mathrm{~mm}$ intervals for most species and $1 \mathrm{~mm}$ intervals for penaeid shrimp. Infaunal organisms from the sediment cores were separated from detritus and plant material, grouped into major phyla, and counted. We identified polychaetes and peracarid crustacea to species. Macro-organic matter (MOM) from sediment cores, which consisted of detritus and live below-ground plant material retained on the sieve, was dried at $100^{\circ} \mathrm{C}$ to a constant weight.

Marsh hydroperiod. Tidal flooding patterns were determined through the use of 3 recording water level gauges. Data were obtained from NOAA's National Ocean Service tide gauge at Pier 21 in the Galveston Channel (Station Number 877-1450), and we installed 2 temporary gauges, one in West Bay at Jamaica Beach and one in East Bay on Bolivar Peninsula (Fig. 1). These temporary gauges consisted of data loggers with pressure transducers located in PVC stilling wells, and they recorded water level every hour during part of the fall season in 1990 and throughout most of 1991 We estimated marsh surface elevations in relation to the nearest tide gauge for each nekton sample by comparing water depth measurements in the sampler with concurrent water level readings on the gauge. The flooding duration for each of these elevations was determined by recording the percentage of water-level records above that elevation on the gauge during any time period. Mean flooding durations in a marsh were calculated using these values plus other randomly collected estimates taken over the course of the study (between 13 and 22 observations per marsh).

Over the period from September 1, 1990 to August 31, 1991, our temporary gauges periodically malfunctioned (not during nekton sampling), and water level data were only available $68 \%$ of the time from the Jamaica Beach gauge and $58 \%$ of the time from the Bolivar gauge. Therefore, we used regression analyses to determine relationships between Pier 21 gauge data and the available data from our temporary gauges for the period from September 1990 through August 1991 The relationship for the Bolivar (BOL) gauge used a $2 \mathrm{~h}$ time lag (the tide reached Bolivar $2 \mathrm{~h}$ after Pier 21) and included 3834 data points; this regression $(\mathrm{BOL}=$ $30.095+0.368$ Pier21 +0.00168 Pier $21^{2}$ ) had an $R^{2}$ of 0.93 . The relationship for the Jamaica Beach (JB) gauge employed a $3 \mathrm{~h}$ time lag and included 5.350 data points; this regression $(\mathrm{JB}=78.426+0.369$ Pier $21+$ 0.00378 Pier $21^{2}$ ) had an $R^{2}$ of 0.90 . These regressions were used to predict missing values on the temporary gauges for calculating flooding duration

Statistical analysis. We used an analysis of variance (ANOVA) model to compare animal densities and other parameters among marshes during each season. A positive relationship between the mean and stan- dard deviation for animal density data indicated that the ANOVA assumption of homogeneity of variances was not met, and a $\ln (y+1)$ transformation was used to correct this heteroscedasticity in the density data. The design was a completely randomized factorial model with Marsh (15 levels) and Habitat (nonvegetated, edge, inner marsh) as the main effects and with 2 replicates per treatment combination. A type I error of 0.05 or less was considered statistically significant. We partitioned the main effect of Marsh with a priori contrasts to compare natural and created marshes. Contrasts also were calculated within Marsh $\times$ Habitat interactions to compare natural and created marshes within habitats. For regression analyses, data from each drop sample were considered independent. We used simple linear regressions to examine the relationship between animal densities (transformed) on the marsh surface (subtidal data were excluded from these analyses) and the age of created marshes ( $\mathrm{n}=40$ in fall and $\mathrm{n}=36$ in spring). Multiple regressions were calculated on data from all marshes to identify factors that might be important in determining the distribution of animals on the marsh surface; a forward stepwise selection technique was used with a partial F-ratio of 4.0 required to enter the model and of 3.996 for removal. Independent variables included annual flooding duration, sediment macro-organic matter, infauna density in sediment cores, sample water depth, water temperature, salinity, dissolved oxygen, and turbidity. Statistical analyses were conducted with SuperANOVA and StatView (Abacus Concepts, Inc., Berkeley, CA, USA, 1991)

\section{RESULTS}

\section{Fishes}

Fishes made up $5.4 \%$ of the fauna caught in the fall drop samples and $43.1 \%$ in the spring Dominant species within marsh vegetation in the fall were the naked goby Gobiosoma bosc and darter goby Gobionellus boleosoma while the bay anchovy Anchod mitchilli was abundant on subtidal nonvegetated bottom (Table 2). In the spring, gulf menhaden Brevoortia patronus dominated the samples (79.1\% of all fish); these fish were found mainly in nonvegetated habitat. Pinfish Lagodon rhomboides and darter goby were abundant in vegetated samples.

There were small but significant differences in fish density between natural and created marshes. In the fall, overall fish densities were significantly higher in natural marshes (Table 3), but the difference in mean densities was only about $10 \%$ (Table 2). This difference was mainly due to densities in the inner marsh (Tables 2 \& 3). In the spring, the overall mean density 
Table 2. Mean densities and (in parentheses) standard errors of common macrofaunal organisms collected from $2.6 \mathrm{~m}^{2} \mathrm{drop}$ samples. Each habitat mean in natural marshes is from 10 samples; habitat means in created marshes are from 18 (spring) or 20 (fall) samples. Species were included if they made up $>2 \%$ of fishes, crustaceans, or molluscs and are listed in order of their overall abundance within these groups. Mean sizes are in mm total length or carapace width

\begin{tabular}{|c|c|c|c|c|c|c|c|c|}
\hline & \multicolumn{4}{|c|}{ Natural marshes } & \multirow[b]{2}{*}{ All habitats } & \multicolumn{2}{|c|}{ Created marshes } & \multirow[b]{2}{*}{ Nonveg } \\
\hline & All habitats & Edge & Inner & Nonveg & & Edge & Inner & \\
\hline \multicolumn{9}{|l|}{ FALL 1990} \\
\hline Total macroiauna & $254.3(48.75)$ & $529.7(88.35)$ & $186.0(37.53)$ & $47.3(7.52)$ & $266.4(51.26)$ & $550.2(127.83)$ & $192.4(34.67)$ & $56.6(9.73)$ \\
\hline Fishes & $15.2(2.19)$ & $16.7(3.32)$ & $10.1(1.86)$ & $18.9(5.20)$ & $13.7(2.94)$ & $20.9(7.60)$ & $6.2\{1.32\}$ & $14 .:(3.90)$ \\
\hline Gobiosoma bosc & $3.8(1.08)$ & $8.9(2.51)$ & $1.3(062)$ & $1.1(0.46)$ & $4.4(1.77)$ & $10.0(5.06)$ & $0.6\{0.31\}$ & $2.7(0.91)$ \\
\hline Anchoa mitchill & $3.5(1.65)$ & $0.0(0.00)$ & $0.0(000)$ & $10.6(4.25)$ & $1.7(1.12)$ & $0.1\{0.07\}$ & $0.0\{0.00\}$ & $5.0(3.30)$ \\
\hline Gobronellus boleosoma & $33(0.82)$ & $5.1(1.86)$ & $4.0(1.28)$ & $0.9(0.59)$ & $1.6(0.32)$ & $2.1(0.60)$ & $1.8(0.68)$ & $1.0(0.29)$ \\
\hline Symphurus plagiusa & $1.2(0.35)$ & $1.0(0.30)$ & $0.4(0.22)$ & $2.2(0.94)$ & $1.7(0.32)$ & $1.5(0.48)$ & $1.1\{0.59\}$ & $2.4(0.55)$ \\
\hline Sclaenops ocellatus & $07(0.26)$ & $0.8(0.55)$ & $0.4(0.22)$ & $0.8(0.51)$ & $1.0(0.57)$ & $2.5(1.69)$ & $0.2(0.08)$ & $0.4(0.17)$ \\
\hline Cynoscion nebulosus & $0.2(0.09)$ & $0.3(0.15)$ & $0.2(0.20)$ & $0.1(0.10)$ & $0.5(0.17)$ & $1.2(0.47)$ & $0.2(0.12)$ & $0.2(0.11)$ \\
\hline Mugil cephalus & $0.1(0.09)$ & $0.2(0.20)$ & $0.2(0.20)$ & $0.0(0.00)$ & $0.4(0.19)$ & $0.4(0.35)$ & $0.8(0.46)$ & $0.0(0.05)$ \\
\hline Brevoortia patronus & $0.0(0.00)$ & $0.0(0.00)$ & $0.0(0.00)$ & $0.0(0.00)$ & $0.5(0.45)$ & $1.4(1.35)$ & $0.0(0.00)$ & $0.0(0.00)$ \\
\hline Crustaceans & $234.5(48.76)$ & $510.1(87.76)$ & $167.0(3879)$ & $26.3(3.81)$ & $243.6(49.05)$ & $523.8(121.20)$ & $167.1\{32.39\}$ & $39.9(7.21)$ \\
\hline Palaemonetes pugio & $105.5(27.28)$ & $253.7(55.34)$ & $62.3\{16.19\}$ & $0.6(0.34)$ & $136.1(31.90)$ & $308.0(80.17)$ & $94.5(22.53)$ & $5.7(2.28)$ \\
\hline Penaeus setiferus & $51.5(16.86)$ & $79.0(27.82)$ & $60.0(41.63)$ & $15.6(2.37)$ & $30.6(9.31)$ & $51.6(25.16)$ & $23.8(11.11)$ & $16.3(3.87)$ \\
\hline Palaemonetes vulgaris & $25.7(11.19)$ & $76.9(27.82)$ & $0.1(0.10)$ & $0.1(0.10)$ & $18.4(7.93)$ & $52.8(22.15)$ & $2.2(1.43)$ & $0.3(0.16)$ \\
\hline Palaemonetes intermedius & $12.0(5.97)$ & $35.6(15.85)$ & $0.2(0.20)$ & $0.2(0.20)$ & $20.5(8.09)$ & $55.7(22.39)$ & $5.6(3.17)$ & $0.3(0.25)$ \\
\hline Callinectes sapidus & $17.1(2.58)$ & $28.3(4.00)$ & $19.7(3.41)$ & $3.3(0.91)$ & $9.5(1.58)$ & $16.5(3.05)$ & $9.2(2.97)$ & $3.0\{0.49\}$ \\
\hline Clibananus vittatus & $8.1(2.65)$ & $8.7(4.23)$ & $15.2(6.14)$ & $0.5(0.34)$ & $10.2(3.67)$ & $20.9(10.45)$ & $7.9(2.49)$ & $1.7(0.60)$ \\
\hline Penaeus aztecus & $8.8(1.86)$ & $17.6(3.06)$ & $4.6(1.14)$ & $4.1(3.14)$ & $3.6(0.73)$ & $6.8\{1.71\}$ & $2.1(0.87)$ & $2.0(0.64)$ \\
\hline Molluscs & $46(1.61)$ & $2.9(0.92)$ & $8.9(4.52)$ & $2.1(0.78)$ & $9.1(2.11)$ & $5.5(1.63)$ & $19.2\{5.44\}$ & $2.7(1.03)$ \\
\hline Littoraria irrorata & $3.4(1.59)$ & $21(0.95)$ & $8.2(4.42)$ & $0.0(0.00)$ & $7.6(2.10)$ & $4.7(1.62)$ & $18.3(5.40)$ & $0.0(0.00)$ \\
\hline \multicolumn{9}{|l|}{ Mean size } \\
\hline Palaemonetes pugio & 20.3 & 7) & 1) & 18. & 14.2 & $15.8(1.18)$ & 13.5 & 2.25) \\
\hline setiferus & $26.1(2.25)$ & $23.6(3.36)$ & $23.9(4.30)$ & 30.5 & $27.0(6.07)$ & $23.4\{2.58\}$ & $39.4(20.66)$ & $20.6(2.78)$ \\
\hline Callinectes sapudus & $12.5(1.16)$ & $14.8(2.25)$ & $13.0(1.60)$ & $8.2\{1.00\}$ & $12.4(1.28)$ & $16.6(2.65)$ & $12.9(1.90)$ & $7.0(0.93)$ \\
\hline Penaeus aztecus & $21.8(2.03)$ & $20.9(1.63)$ & $20.6(2.19)$ & $25.9\{8.92\}$ & $21.5(1.65)$ & $23.0(2.28)$ & $27.0(3.77)$ & $14.4(1.17)$ \\
\hline \multicolumn{9}{|l|}{ SPRING 1991} \\
\hline Total macrofauna & $262.9(84.32)$ & $179.3(30.16)$ & $222.1(45.12)$ & $387.3(251.20)$ & $135.7(22.26)$ & $126.5(16.85)$ & $173.3(26.47)$ & $107.2(59.28)$ \\
\hline Fishes & $134.4(86.66)$ & $18.7(3.28)$ & $14.8(2.64)$ & $369.7(251.68)$ & $46.9(20.13)$ & $27.4(5.49)$ & $19.9(5.48)$ & $93.3(59.48)$ \\
\hline Brevoor & $128.3(93.06)$ & $21\}$ & $0.00)$ & $358.9(252.09)$ & 29.61 & 5.2 & $0.4(0.28)$ & $83.1(59.69)$ \\
\hline Lagodon rhomboides & $5.4(1.31)$ & $8.6(2.20)$ & $7.0(2.77)$ & $0.6(0.27)$ & $3.8(1.36)$ & $8.3(3.73)$ & $2.1(1.11)$ & $0.8(0.61)$ \\
\hline Gobionellus boleosoma & $1.9(0.69)$ & $2.9(1.76)$ & $1.5(0.92)$ & $1.3(0.70)$ & $3.0(1.23)$ & $4.7(3.12)$ & $3.6(1.92)$ & $0.8(0.39)$ \\
\hline Mugil curema & $0.6(0.37)$ & $0.7(0.70)$ & $1.0(0.89)$ & $0.0(0.00)$ & $2.9(1.49)$ & $1.8(1.72)$ & $6.8(4.04)$ & $0.0(0.00)$ \\
\hline Crustaceans & $115.8(20.07)$ & $158.6(31.67)$ & $171.2(35.28)$ & $17.6(5.55)$ & $83.9(12.68)$ & $98.6(16.66)$ & $140.6(26.74)$ & $12.4(2.87)$ \\
\hline Palae. & $615(15.60)$ & $76.8(26.69)$ & $107.5(30.99)$ & & $49.3(9.74)$ & $57.7(16.15)$ & 88.91 & $1.3(0.55)$ \\
\hline Penaeus aztecus & $38.3(7.50)$ & $61.2(17.75)$ & $41.0(8.10)$ & $12.8\{5.64\}$ & $9.5(1.34)$ & $13.0(1.84)$ & $11.7(3.08)$ & $3.8(1.06)$ \\
\hline Chbanarius vittâtus & $5.1(1.80)$ & $7.3(3.09)$ & $7.2(4.29)$ & $0.9(0.41)$ & $10.2(5.24)$ & $9.6(3.09)$ & $19.7(15.39)$ & $1.3(0.75)$ \\
\hline Callinectes sapıdus & $6.2(1.29)$ & $6.8(1.87)$ & $11.3(2.41)$ & $0.4(0.27)$ & $5.4(0.89)$ & $9.8(2.01)$ & $5.7(0.99)$ & $0.7(0.19)$ \\
\hline Penaeus setiferus & $0.7(0.58)$ & $0.4\{0.40\}$ & $0.0(0.00)$ & $1.7(1.70)$ & $2.8(0.84)$ & $1.2(0.86)$ & $3.3(1.73)$ & $3.8(1.61)$ \\
\hline Moll & & & & & & 0.5 & 12.8 & $1.5(0.61)$ \\
\hline Littoraria Irrorata & $12.6(6.39)$ & $1.8(1.13)$ & $36.1(17.36)$ & $0.0\{0.00\}$ & $4.2(1.81)$ & $0.0(0.06)$ & $12.4(4.96)$ & $0.0(0.00)$ \\
\hline \multicolumn{9}{|l|}{ Mean size } \\
\hline Palaemonetes pugio & $26.8(1.31)$ & $26.5(178)$ & $28.6(1.50)$ & 12.5 & $20.2(1.27)$ & $23.9(1.61)$ & $19.6\{1.91\}$ & $14.3(2.92)$ \\
\hline Penaeus aztecus & $40.1(1.56)$ & $40.2(2.10)$ & $37.0(2.61)$ & 43.013 & $41.2(1.66)$ & $38.0(3.23)$ & $42.6\{2.44\}$ & $44.1(2.43)$ \\
\hline Callinectes sapidus & $26.7(1.57)$ & $24.4(2.61)$ & $29.3(2.08)$ & $25.0(2.50)$ & $24.0(2.43)$ & $21.1(2.53)$ & $27.6(3.31)$ & $22.5(10.42)$ \\
\hline
\end{tabular}

of fishes (mostly gulf menhaden on subtidal bottom) in natural marshes was 2.9 times higher than in created marshes, but the high variability in the samples prevented the detection of any statistical significance (Table 3). However, densities of Lagodon rhomboides, the dominant fish on the marsh surface, were significantly higher (ANOVA contrast p-value $<0.001$ ) in natural compared with created marshes (Table 2). There was no apparent relationship between fish density and the age of created marshes (Fig. 2; all p-values $>0.09$ for age/density regressions).

\section{Decapod crustaceans}

Decapod crustaceans dominated the fauna in drop samples $(91.7 \%$ in the fall and $52.6 \%$ in the spring). In the fall, 3 species of grass shrimp Palaemonetes spp. made up $68.3 \%$ of the crustaceans. Juveniles of commercially-important species including white shrimp Penaeus setiferus, blue crab Callinectes sapidus, and brown shrimp Penaeus aztecus were also abundant in the marshes during this season (Table 2). In the spring, the daggerblade grass shrimp Palaemonetes pugio was 
most abundant ( $56.3 \%$ of crustaceans) along with brown shrimp, thinstripe hermit crab Clibanarius vittatus, and blue crab. Most crustaceans were found within vegeta- tion; $95 \%$ were collected in edge or inner marsh samples. The density of crustaceans as a group was not significantly different between natural and created

Table 3. ANOVA results for anmmals collected in drop samples. The main effect of Marsh and the Marsh $\times$ Habitat interaction. were partitioned through contrasts comparing natural (Nat) and created (Crt) marshes and the 3 habitats examined (Edge, Inner marsh (Inner), and Nonvegetated bottom (NV)]. Data were ln(y+1)-transformed

\begin{tabular}{|c|c|c|c|c|c|c|c|c|c|c|c|c|c|}
\hline \multirow{2}{*}{$\begin{array}{l}\text { Source of } \\
\text { variance }\end{array}$} & \multicolumn{3}{|c|}{ Fall 1990} & \multicolumn{3}{|c|}{ Spring 1991} & \multirow{2}{*}{$\begin{array}{l}\text { Source of } \\
\text { variance }\end{array}$} & \multicolumn{3}{|c|}{ Fall 1990} & \multicolumn{3}{|c|}{ Spring 1991} \\
\hline & $\mathrm{df}$ & SS & $p$ & $\mathrm{df}$ & $\mathrm{SS}$ & $p$ & & $\mathrm{df}$ & SS & $\mathrm{p}$ & $\mathrm{df}$ & SS & $\mathrm{p}$ \\
\hline Fishes & & & & & & & Penaeus setiferus & & & & & & \\
\hline Marsh & 14 & 33.05 & $<0.001$ & 13 & 36.21 & 0.026 & Marsh & 14 & 100.25 & $<0.001$ & & & \\
\hline Nat vs Crt & 1 & 4.14 & 0.004 & 1 & 1.37 & 0.303 & Nat vs Crt & 1 & 11.82 & 0.002 & & & \\
\hline Habitat & 2 & 6.35 & 0.002 & 2 & 3.10 & 0.302 & Habitat & 2 & 10.98 & 0.010 & & & \\
\hline Marsh $\times$ Habitat & 28 & 34.98 & 0.001 & 26 & 48.34 & 0.126 & Marsh $\times$ Habitat & 28 & 94.91. & $<0.001$ & & & \\
\hline Edge; Nat vs Crt & 1 & 1.24 & 0.105 & 1 & 0.07 & 0.812 & Edge; Nat vs Crt & 1 & 3.45 & 0.079 & & & \\
\hline Inner; Nat vs Crt & 1 & 2.79 & 0.017 & 1 & 0.03 & 0.874 & Inner; Nat vs Crt & 1 & 8.45 & 0.007 & & & \\
\hline NVi Nat vs Crt & 1 & 0.55 & 0.278 & 1 & 4.47 & 0.066 & NV; Nat vs Crt & 1 & 1.41 & 0.255 & & & \\
\hline $\mathrm{Crt}_{i}$ Edge vs NV & 1 & 0.10 & 0.633 & 1 & 0.32 & 0.615 & Crt; Edge vs NV & 1 & 0.80 & 0.392 & & & \\
\hline $\mathrm{Crt}_{i}$ Edge vs Inner & 1 & 3.68 & 0.007 & 1 & 1.28 & 0.318 & Crt $_{\text {Edge vs Inner }}$ & 1 & 9.78 & 0.004 & & & \\
\hline Nat; Edge vs NV & 1 & 0.00 & 0.889 & 1 & 2.81 & 0.142 & Nat; Edge vs NV & 1 & 1.45 & 0.249 & & & \\
\hline Nat; Edge vs Inner & 1 & 0.76 & 0.201 & 1 & 0.20 & 0.690 & Nat; Edge vs Inner & 1 & 1.69 & 0.215 & & & \\
\hline Error & 45 & 20.39 & & 42 & 52.75 & & Error & 45 & 48.08 & & & & \\
\hline Crustaceans & & & & & & & Callinectes sapidus & & & & & & \\
\hline Marsh & 14 & 22.23 & $<0.001$ & 13 & 25.83 & $<0.001$ & Marsh & 14 & 28.55 & $<0.001$ & 13 & 13.87 & $<0.001$ \\
\hline Nat vs Crt & 1 & 0.83 & 0.161 & 1 & 2.64 & 0.016 & Nat vs Crt & 1 & 8.14 & $<0.001$ & 1 & 0.07 & 0.581 \\
\hline Habitat & 2 & 88.86 & $<0.001$ & 2 & 94.20 & $<0.001$ & Habitat & 2 & 36.49 & $<0.001$ & 2 & 47.82 & $<0.001$ \\
\hline Marsh $\times$ Habitat & 28 & 57.81 & $<0.001$ & 26 & 19.48 & 0.046 & Marsh $\times$ Habitat & 28 & 31.59 & $<0.001$ & 26 & 14.49 & 0.003 \\
\hline Edge; Nat vs Crt & . & 1.60 & 0.054 & 1 & 1.16 & 0.105 & Edge $_{i}$ Nat vs Crt & 1 & 4.80 & $<0.001$ & 1 & 0.36 & 0.205 \\
\hline Inner; Nat vs Crt & 1 & 0.56 & 0.247 & 1 & 0.73 & 0.193 & Inner: Nat vs Crt & 1 & 7.75 & $<0.001$ & 1 & 2.53 & 0.001 \\
\hline NV Nat vs Crt & 1 & 0.19 & 0.498 & 1 & 0.78 & 0.182 & NV; Nat vs Crt & 1 & 0.00 & 0.957 & 1 & 030 & 0.244 \\
\hline Crt; Edge vs NV & 1 & 48.28 & $<0.001$ & 1 & 40.88 & $<0.001$ & Crt; Edge vs NV & 1 & 15.62 & $<0.001$ & 1 & 23.98 & $<0.001$ \\
\hline Crt; Edge vs Inner & 1 & 8.02 & $<0.001$ & 1 & 0.35 & 0.366 & $\mathrm{Crt}_{;}$Edge vs Inner & 1 & 3.77 & 0.002 & 1 & 1.16 & 0.025 \\
\hline Nat; Edge vs NV & 1 & 40.81 & $<0.001$ & 1 & 24.38 & $<0.001$ & Nat; Edge vs NV & 1 & 22.28 & $<0.001$ & 1 & 13.01 & $<0.001$ \\
\hline Nat; Edge vs Inner & 1 & 5.99 & $<0.001$ & 1 & 0.06 & 0.704 & Nat $_{i}$ Edge vs Inner & 1 & 0.74 & 0.155 & 1 & 1.27 & 0.019 \\
\hline Error & 45 & 18.44 & & 42 & 17.64 & & Error & 45 & 15.93 & & 42 & 9.02 & \\
\hline Palaemonetes pugic & & & & & & & Infauna & & & & & & \\
\hline Marsh & 14 & 33.81 & 0.153 & 13 & 26.65 & 0.288 & Marsh & 14 & 36.24 & 0.003 & 13 & 75.43 & $<0.001$ \\
\hline Nat vs Crt & 1 & 0.68 & 0.519 & 1 & 0.09 & 0.813 & Nat vs Crt & 1 & 3.19 & 0.064 & 1 & 2.27 & 0.122 \\
\hline Habitat & 2 & 259.78 & $<0.001$ & 2 & 204.08 & $<0.001$ & Habitat & 2 & 0.40 & 0.800 & 2 & 0.50 & 0.761 \\
\hline Marsh $\times$ Habitat & 28 & 87.79 & 0.023 & 26 & 49.66 & 0.332 & Marsh $\times$ Habitat & 28 & 42.69 & 0.051 & 26 & 32.60 & 0.175 \\
\hline Edge; Nat vs Crt & 1 & 2.03 & 0.268 & 1 & 0.79 & 0.492 & Edge; Nat vs Crt & 1 & 1.70 & 0.174 & 1 & 4.79 & 0027 \\
\hline Inner; Nat vs Crt & 1 & 0.74 & 0.503 & 1 & 0.52 & 0.576 & Inner; Nat vs Crt & 1 & 0.30 & 0.565 & 1 & 0.21 & 0.635 \\
\hline NV; Nat vs Crt & 1 & 3.99 & 0.123 & 1 & 1.18 & 0.403 & $\mathrm{NV}_{i}$ Nat vs Crt & 1 & 5.47 & 0.017 & 1 & 0.64 & 0.408 \\
\hline Crt: Edge vs NV & & 131.97 & $<0.001$ & 1 & 57.30 & $<0.001$ & $\mathrm{Crt}_{i}$ Edge vs NV & 1 & 0.06 & 0.797 & 1 & 0.47 & 0.478 \\
\hline $\mathrm{Crt}_{\text {; Edge vs Inner }}$ & 1 & 10.20 & 0.016 & 1 & 6.80 & 0.049 & Crt; Edge vs Inner & 1 & 0.18 & 0.653 & 1 & 0.49 & 0.466 \\
\hline Nat; Edge vs NV & & 122.96 & $<0.001$ & 1 & 54.55 & $<0.001$ & Nat; Edge vs NV & 1 & 0.53 & 0.446 & 1 & 0.64 & 0.407 \\
\hline Nat; Edge vs Inner & 1 & 17.96 & 0.002 & 1 & 3.22 & 0.170 & Nat; Edge vs Inner & 1 & 1.69 & 0.174 & 1 & 3.38 & 0.061 \\
\hline Error & 45 & 72.74 & & 42 & 69.50 & & Error & 45 & 39.91 & & 41 & 37.30 & \\
\hline Penaeus aztecus & & & & & & & Streblospio benedi & & & & & & \\
\hline Marsh & 14 & 30.77 & $<0.001$ & 13 & 45.64 & $<0.001$ & Marsh & 14 & 74.19 & $<0.001$ & 13 & 62.42 & $<0.001$ \\
\hline Nat vs Crt & 1 & 10.75 & $<0.001$ & 1 & 30.67 & $<0.001$ & Nat vs Crt & 1 & 4.72 & 0.029 & 1 & 4.83 & 0.035 \\
\hline Habitat & 2 & 24.14 & $<0.001$ & 2 & 30.02 & $<0.001$ & Habitat & 2 & 4.52 & 0.100 & 2 & 2.98 & 0.244 \\
\hline Marsh $\times$ Habitat & 28 & 4226 & $<0.001$ & 26 & 36.74 & 0.001 & Marsh $\times$ Habitat & 28 & 81.11 & $<0.001$ & 26 & 34.61 & 0.218 \\
\hline Edge; Nat vs Crt & 1 & 10.52 & $<0.001$ & 1 & 11.25 & $<0.001$ & Edge; Nat vs Crt & 1 & 0.78 & 0.366 & 1 & 7.01 & 0.012 \\
\hline Inner; Nat vs Crt & 1 & 5.04 & 0.001 & 1 & 13.54 & $<0.001$ & Inner; Nat vs Crt & 1 & 0.66 & 0.405 & 1 & 0.00 & 0.950 \\
\hline NV: Nat vs Crt & 1 & 0.04 & 0.768 & 1 & 6.54 & $<0.001$ & NV; Nat vs Crt & 1 & 13.63 & $<0.001$ & 1 & 1.30 & 0.266 \\
\hline Crt; Edge vs NV & 1 & 6.22 & $<0.001$ & 1 & 15.83 & $<0.001$ & $\mathrm{Crt}_{\text {: Edge vs NV }}$ & 1 & 0.69 & 0.395 & 1 & 0.07 & 0.796 \\
\hline Crt; Edge vs Inner & 1 & 7.38 & $<0.001$ & 1 & 2.50 & 0.028 & Crt; Edge vs Inner & 1 & 0.39 & 0.519 & 1 & 003 & 0.875 \\
\hline Nat; Edge vs NV & 1 & 19.43 & $<0.001$ & 1 & 13.45 & $<0.001$ & Nat $_{i}$ Edge vs NV & 1 & 3.41 & 0.062 & 1 & 2.54 & 0.122 \\
\hline Nat; Edge vs Inner & 1 & 776 & $<0.001$ & 1 & 0.79 & 0.207 & Nat; Edge vs Inner & 1 & 3.65 & 0.054 & 1 & 6.42 & 0.016 \\
\hline Error & 45 & 18.49 & & 42 & 20.22 & & Error & 45 & 41.93 & & 42 & & \\
\hline
\end{tabular}


marshes in the fall (Tables 2 \& 3); but in the spring, the density was significantly higher in natural marshes (115.8 animals per $2.6 \mathrm{~m}^{2}$ sample) compared with created marshes (83.9 animals per $2.6 \mathrm{~m}^{2}$ sample). There was no evidence for a relationship between marsh age and overall crustacean density (Fig 2; regression $p$-values $>0.20$ )

All caridean shrimp in the genus Palaemonetes (grass shrimp) showed a strong affinity for marsh vegetation, and most were found in edge habitat (Table 2). P. pugio was abundant during both seasons, and there were no significant differences in density between natural and created marshes (Table 3). P. vulgaris and $P$. intermedius occurred mainly in fall samples and almost exclusively in edge habitat. There was no significant difference in densities of $P$. intermedius between natural and created marshes in fall (ANOVA contrast $\mathrm{p}$-values > 0.12 ), but $P$. vulgaris was found in significantly greater numbers in natural marshes (ANOVA contrast in edge habitat, p-value $<0.001$ ). Although densities of $P$. pugio were not different among the marshes, the mean size of these shrimp was significantly larger (by 33 to $43 \%$ ) in natural marshes compared with created marshes (Table 2, ANOVA contrast p-values < $0.003)$. The size of daggerblade grass shrimp also differed significantly among habitats (ANOVA p-values $<0.028$ ), with the largest mean sizes (fall $17.5 \mathrm{~mm} \mathrm{TL}$, spring $25.0 \mathrm{~mm}$ ) occurring in edge habitat and the smallest on nonvegetated bottom (fall $13.7 \mathrm{~mm}$, spring $14.1 \mathrm{~mm}$ ). Neither density nor size of $P$. pugio was significantly related to the age of created marshes (regression p-values $>0.26$ )

Mean densities of the 3 commercially-important crustaceans (Penaeus aztecus, Penaeus setiferus, Callinectes sapidus) were greatest in edge habitat and were significantly higher in natural marshes compared with created marshes (Tables $2 \& 3$ ). Densities of $P$. aztecus in natural marshes were 2.4 and 4.0 times higher than in created marshes during fall and spring respectively, while densities of $C$. sapidus were 1.8 and 2.0 times higher in natural marshes during these sampling periods. $P$. setiferus was mainly present in fall samples, and densities were 1.7 times higher in natural marshes than in created marshes. During spring, $P$. setiferus only occurred in 20 of the 84 samples collected. There were no apparent relationships between densities of any of these decapod crustaceans and age of created marshes, and regressions with age were not significant ( $\mathrm{p}$-values $>0.08$ ). The mean size of $P$ aztecus and $P$. setiferus did not differ among habitats
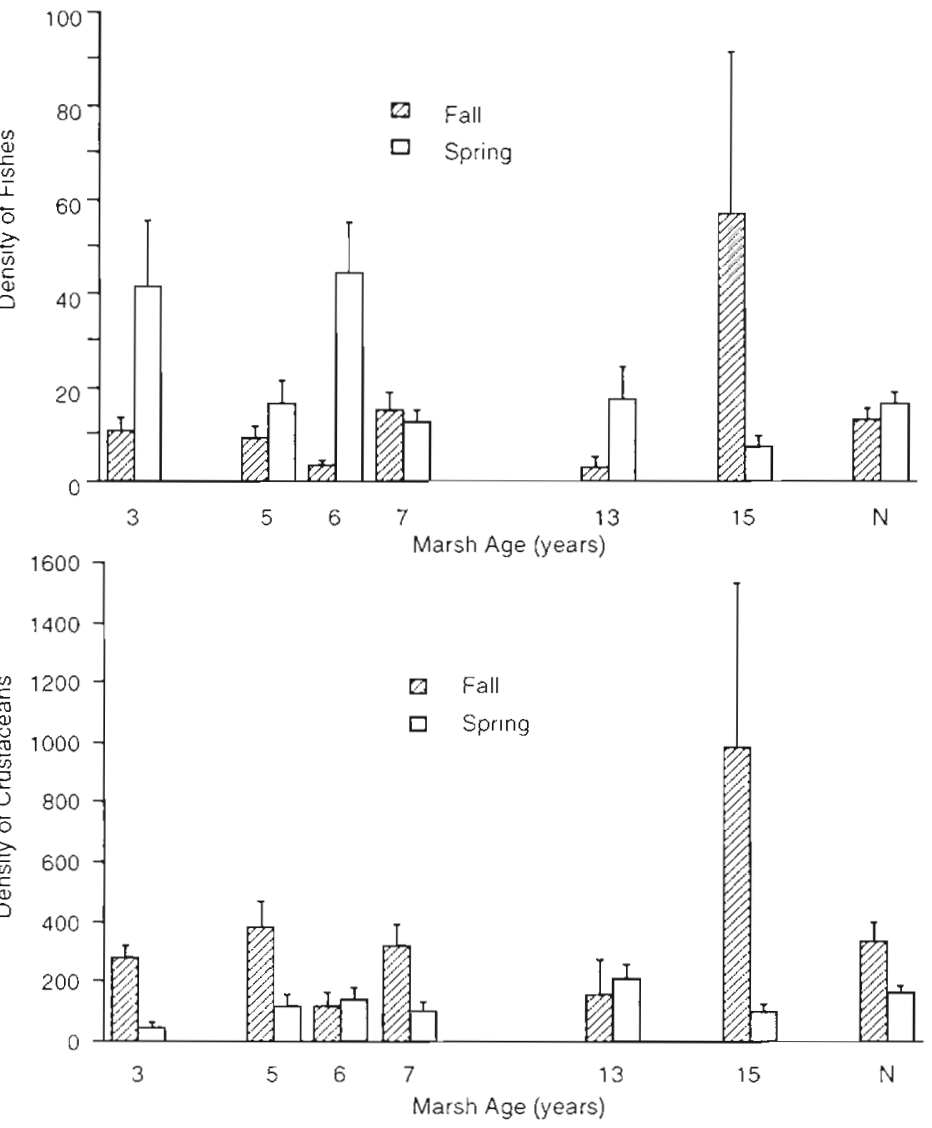

Fig. 2. Densities of fishes and decapod crustaceans at marshes of different ages (yr) and at natural marshes $(N)$. Mean densities per $2.6 \mathrm{~m}^{2} \mathrm{drop}$ sample (error bar represents $1 \mathrm{SE}$ ) are shown for all samples collected n the marsh surface (edge and inner marsh habitats). See Table 1 to identify marshes in each age category

or marshes (Table 2, ANOVA p-values $>0.20$ ). The size of $C$. sapidus could only be analyzed in fall (only 25 size observations were available in spring); and although there were differences among marshes (ANOVA p-value $=0.035$ ), blue crab size was not significantly different between natural and created marshes (contrast p-values $>0.65$ ). Crab size varied among habitats (ANOVA p-value $=0.005$ ), and blue crabs on nonvegetated bottom (mean $\mathrm{CW}=7.3 \mathrm{~mm}$ ) were significantly smaller than crabs in both the edge (15.9 $\mathrm{mm}$ ) and inner marsh $\left(12.9^{\prime} \mathrm{mm} \mathrm{CW}\right.$ ) habitat (Scheffe's multiple comparison test, alpha $=0.05$ ).

The thinstripe hermit crab Clibanarius vittatus was present on the marsh surface during both fall and spring (Table 2). During both seasons, mean densities of this species were greater in the created marshes compared with natural marshes, but these differences were not statistically significant (ANOVA contrast $p$-values $>0.06$ ). Densities of thinstripe hermit crabs were significantly related to the age of created marshes in fall (regression p-value $<0.001$ ). This rela- 
tionship was negative with highest densities in the youngest marshes; marsh age could explain $28 \%$ of the variability in density of the species.

\section{Molluscs}

The marsh periwinkle Littoraria irrorata comprised $82 \%$ of molluscs in fall and $93 \%$ in spring (Table 2). Almost all (94\%) marsh periwinkles were collected within vegetated habitat, and mean densities were highest in inner marsh samples. In ANOVAs there were significant differences among marshes ( $p$ values < 0.02) during both seasons, but only in the spring was there a difference between created and natural marshes (contrast $p$-value $=0.025$ ); densities in natural marshes were 3 times higher than those in created marshes. This difference appeared to be mainly due to densities in the edge habitat

\section{Sediment cores}

There was little seasonal variability in macroorganic matter (Table 4), and mean dry weight (both seasons combined) was significantly higher (ANOVA contrast $\mathrm{p}$-values all < 0.006) in natural marshes $(6.3 \mathrm{~g}$ $\left.\operatorname{core}^{-1}, \mathrm{n}=57, \mathrm{SE}=0.65\right)$ compared with created marshes $\left(2.2 \mathrm{~g}_{\text {core }}{ }^{-1}, \mathrm{n}=112, \mathrm{SE}=0.35\right)$. The amount of $\mathrm{MOM}$ in sediments also varied among habitats, and values were significantly higher within vegetation than on nonvegetated bottom (Table 4, ANOVA contrast $\mathrm{p}$-values $<0.001$ ).

Infauna were dominated by annelid worms (88.8 and $93.5 \%$ of the total organisms in the fall and spring, respectively); the most abundant was the polychaete Streblospio benedicti. Densities of overall infauna and $S$. benedicti were not significantly different among the 3 habitats examined during either season (Table 3 ). In fall, mean densities of both total infauna and $S$. benedicti in all habitats were higher in natural marshes than in created marshes, but the difference was only significant on nonvegetated bottom (Tables 3 \& 4). In spring, mean densities of total infauna in natural and created marshes were generally similar; but in the edge habitat there was a significant difference (Table 3), and the log-transformed density was higher in natural marshes. Spring densities of $S$. benedicti in all habitats were significantly higher in natural marshes than in created marshes (Table 3). Fall densities of another abundant polychaete, Capitella capitata, were significantly higher in natural marshes than in created marshes (inner marsh, ANOVA contrast pvalue $=0.026$ ); this comparison was not significant in spring. Densities of peracarid crustaceans (mainly amphipods and the tanaid Hargeria rapax] were also significantly higher in natural marshes than in created marshes (ANOVA contrast p-values $<0.001$ ) i natural marsh densities were 8.4 times higher in fall and 1.3 times higher in spring (Table 4)

MOM was positively related to the age of created marshes (regression p-value $=0.009, \mathrm{n}=74$ ), although the relationship only explained $9 \%$ of the variability in MOM. There were no apparent positive relationships between marsh age and infaunal density; regressions between the age of created marshes and densities of total infauna, annelid worms, Streblospio benedicti (spring only), Capitella capitata, and peracarid crustaceans were not statistically significant (all regression p-values $>0.10$ ). Fall densities of $S$. benedicti on the marsh surface were highest in the youngest marshes, and there was a significant negative regression ( $\mathrm{p}$ value $=0.01$ ) with marsh age that could explain $16 \%$ of the variability within created marshes.

\section{Species richness}

Species richness in marshes was examined by counting the total number of species (within fishes, decapod crustaceans, and infauna) collected in the 6 samples (15.6 $\mathrm{m}^{2}$ of area for nekton and $471 \mathrm{~cm}^{2}$ for infauna) from each marsh. The mean number of fish species from all marshes was 9.9 in the fall and 12.8 in the spring, while the mean number of decapod species was 12.2 in fall and 7.8 in spring. There were no significant differences in species richness for these groups between natural and created marshes (1-way ANOVA, $p$-values $>0.48$ ). Species richness within the infauna, however, appeared greater in natural marshes than in created marshes. The mean number of infaunal species identified in fall was 14.2 in natural marshes and 11.2 in created marshes, but this difference was not statistically significant (ANOVA p-values $=0.22$ ). The difference between natural (15.2 species) and created (10.2 species) marshes in spring, however, was statistically significant (ANOVA p-value $=0.032$ )

\section{Physical and chemical parameters}

Statistically significant differences were generally found among habitats and marshes (including the contrasts between created and natural marshes) for the physical and chemical parameters measured, but differences in temperature, salinity, and dissolved oxygen did not appear to be biologically meaningful. In fall, mean values among the 3 habitats ranged from 25.2 to $26.1^{\circ} \mathrm{C}$ for temperature, 19.8 to $20.2 \mathrm{ppt}$ for salinity, and 5.6 to $7.0 \mathrm{ppm}$ for dissolved oxygen. In spring, these 
Table 4. Mean densities and (1n parentheses) standard errors of common infaunal organisms $\geq 30$ individuals collected) and sediment macro-organic matter collected from $78.5 \mathrm{~cm}^{2}$ sediment cores taken within each drop sample. Each habitat mean in natural marshes is from 10 cores; habitat means in created marshes are from 18 (spring) or 20 (fall) cores. All marsh cores (Edge and Inner marsh) were taken between clumps of vegetation

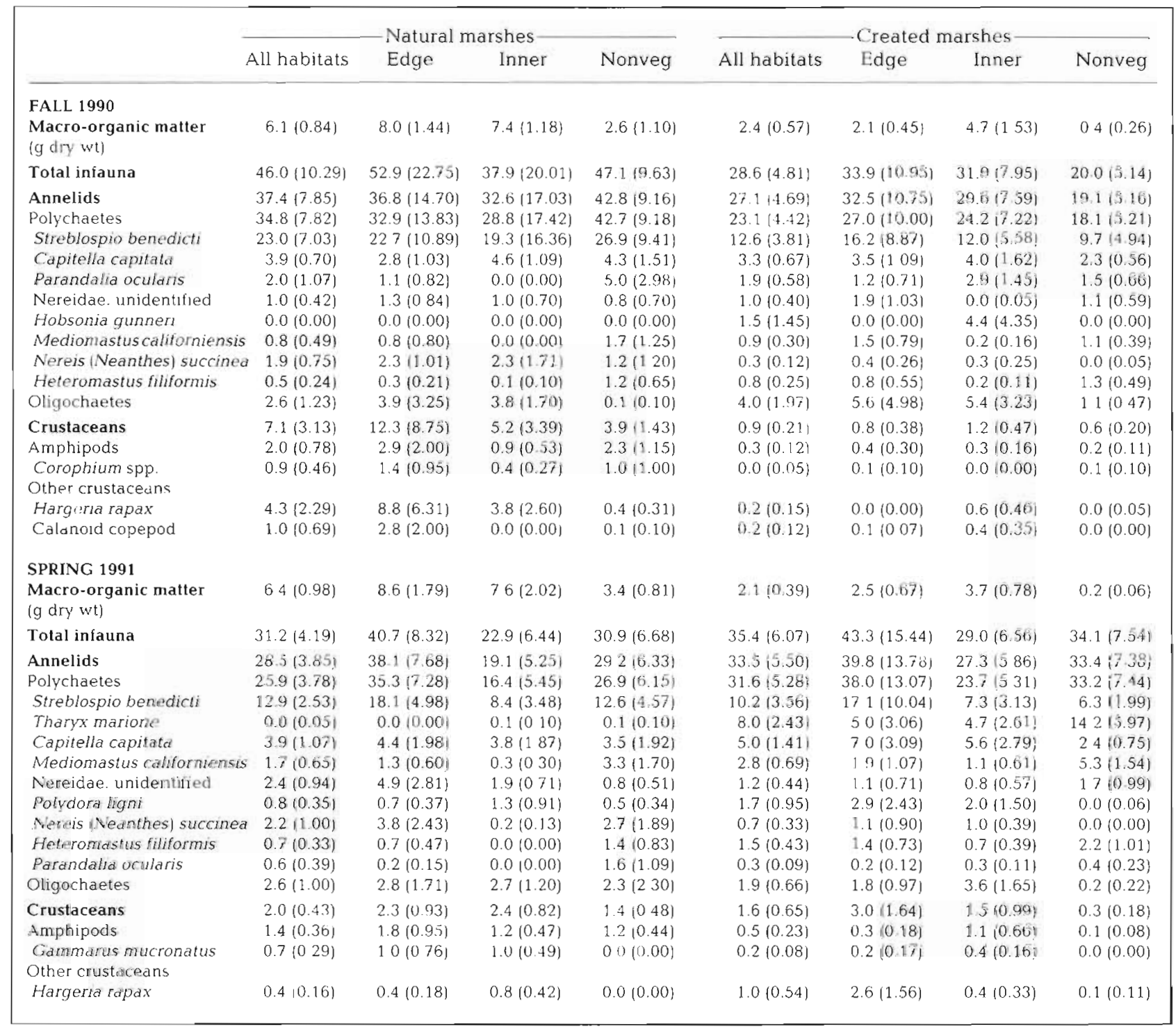

ranges were 27.2 to $28.1^{\circ} \mathrm{C}, 9.3$ to $9.8 \mathrm{ppt}$, and 7.2 to $7.7 \mathrm{ppm}$. Mean values for natural/created marshes (all contrast $\mathrm{p}$-values $<0.025$ except temperature in spring, $\mathrm{p}$-value $=0.45 \mathrm{f}$ were $26.3 / 25.2^{\circ} \mathrm{C}, 19.8 / 20.1 \mathrm{ppt}$, and 7.0/6.1 ppm (DO) in fall and $27.8 / 27.7^{\circ} \mathrm{C}, 10.3 / 9.2 \mathrm{ppt}$, and $7.1 / 7.7 \mathrm{ppm}$ in spring. These small differences are unlikely to be biologically important for estuarine organisms. Differences in turbidity between natural and created marshes, however, were large and perhaps related to the substratum of dredged material in many created marshes. In fall, the mean turbidity in natural marshes was 17.2 FTU ( $\mathrm{n}=30, \mathrm{SE}=2.13) \mathrm{com}$ pared with 50.3 FTU $(n=60, \mathrm{SE}=8.32)$ in created marshes. In spring, the values were 5.9 FTU ( $\mathrm{n}=30$, $\mathrm{SE}=0.58)$ in natural marshes and $15.5 \mathrm{FTU}(\mathrm{n}=54$, $\mathrm{SE}=2.76$ ) in created marshes. The contrasts in the ANOVAs for these comparisons were highly significant ( $p$-values $<0.001$ ).

The extent of tidal flooding determines availability of the marsh surface for estuarine nekton. Over the $1 \mathrm{yr}$ period from September 1, 1990 to August 31, 1991, the flooding duration of the marsh edge habitat for the 5 natural marshes ranged between 74 and $80 \%$ (Fig. 3). Flooding of the edge habitat in created marshes was more variable (between 43 and 91\%), reflecting the substantial variability in elevation of these marshes. 

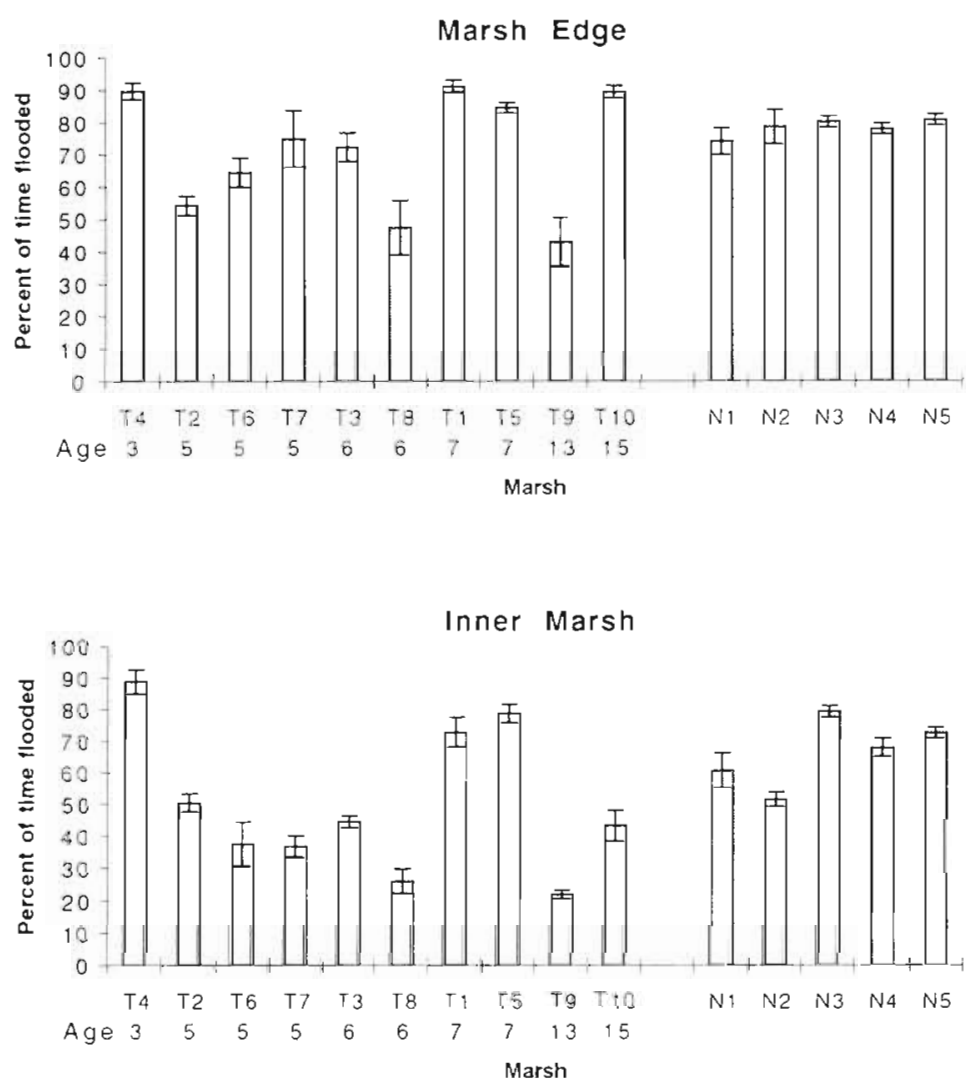

Fig. 3. Duration of tidal inundation during 1 yr (September 1, 1990 through August 31, 1991). Created marshes (T1 to T10) are arranged in order of their age in years at the time of sampling. The mean percentage of time that each marsh habitat was flooded was determined from 3 water level gauges in the bay system. The standard error bars shown represent variability in the elevation of the marsh surface and in the water level differences between the marsh and the nearest gauge

The overall mean flooding duration was $78.1 \%(n=5$. $\mathrm{SE}=1.16)$ for natural marshes and $71.0 \%(\mathrm{n}=10, \mathrm{SE}=$ 5.74) for created marshes. Annual flooding of inner marsh habitats was lower and even more variable due to differences in marsh slopes (Fig. 3). The overall mean flooding duration for the inner marsh was $66.3 \%$ $(\mathrm{n}=5, \mathrm{SE}=4.77$ ) for natural marshes and $50.1 \%$ ( $\mathrm{n}=$ $10, \mathrm{SE}=7.14)$ for created marshes. There was a seasonal pattern to marsh flooding, and mean flooding durations were highest during the spring and fall (Fig. 4). Edge habitat in natural marshes during April and May was flooded between 96 and $99 \%$ of the time, while the inner marsh during these periods was flooded between 88 and $96 \%$ of the time. Even during seasonal low-water periods such as in July and August, the natural marshes were flooded between 44 and $65 \%$ of the time. The lowest monthly mean flooding duration (27\%) occurred during July in the inner marsh habitat of created marshes. As in the annual flooding data, created marshes exhibited much higher variability in monthly flooding durations than the natural marshes.

\section{Relationships between nekton densities and environmental variables}

Multiple regression models used to explore relationships between nekton densities on the marsh surface and environmental factors indicated that the strongest and most consistent relationships were with annual tidal flooding and sample water depth (Table 5). The most important variable for fishes appeared to be water depth, with higher densities of fishes in deeper water. For some fish species, salinity, water temperature, and dissolved oxygen could explain significant portions of the variability in density. Densities of decapod crustaceans were mainly related to our tidal flooding variable, with higher densities in marsh areas that were flooded for extensive periods throughout the year. This relationship was more apparent in fall samples. There is an obvious relationship between water depth and tidal flooding, and the variables were positively correlated $(r=0.74$ in fall and 0.93 in spring, p-values $<0.001$ ) Therefore, any relationship between animal densities and either of these variables could be caused by a relationship with the other variable. However, water depth and tidal flooding are not necessarily interdependent because they function on different time scales as an expression of elevation. We included both variables in the model because of their potential for measuring very different relationships. For example, densities of Clibanarius vittatus in fall and all decapods in spring were positively related to flooding but negatively related to water depth, suggesting that some crustaceans may select for both shallow water and low elevation habitats that are flooded most of the year Densities of Penaeus aztecus during both seasons and $P$ setiferus in fall were strongly related (negatively) to water turbidity in the analyses; but both low densities of these animals and high turbidities occurred in created marshes, and this density/turbidity relationship may have been caused by some other difference between natural and created marshes. Other variables such as water temperature and salinity were periodically important in the models for some species of crustaceans. The amount of macro-organic matter and the abundance of infauna in sediment cores seldom explained much variability in densities of either fishes 
or decapods. Densities of the dominant mollusc, Littoraria irrorata, were not significantly related to any of the variables included in the regression models.

Marsh elevation and flooding duration were variable in created marshes and appeared important in explaining densities of nekton. To test whether these variables could explain the overall differences between natural and created marshes, we compared mean densities of fishes and dominant crustaceans among natural marshes, low-elevation created marshes (T1, T3, T4, T5, T7 \& T10), and high-elevation created marshes ( 2 2, T6, T8 \& T9). Created marshes were assigned to these elevation categories on the basis of marsh edge flooding durations shown in Fig. 3. Only data from the vegetated habitats (edge and inner marsh) were included in this analysis, and we compared marsh categories using contrasts from within the Marsh effect of a 1-way ANOVA. In general, low-elevation marshes were more similar to natural marshes than high-elevation marshes (Table 6). However, significant differences persisted between natural and low-elevation created marshes for densities of $\mathrm{Pe}$ naeus aztecus and Callinectes sapidus in both the fall and the spring.

\section{DISCUSSION}

The function and value of salt marshes for juvenile fishery species and other nekton is difficult to measure. Salt marsh habitats in the northern Gulf of Mexico are directly exploited by many nekton species (Zimmerman \& Minello 1984, Thomas et al. 1990, Baltz et al 1993, Rozas \& Reed 1993, Peterson \& Turner 1994); and for some species, such as brown shrimp and blue crabs, salt marshes have been shown to function by increasing growth and reducing mortality in comparison with nonvegetated bay bottom (Minello et al. 1989, Thomas 1989, Minello \& Zimmerman 1991, Heck \& Coen 1995). However, there is evidence that salt marsh functions vary for different nekton species and vary within estuaries and coastal regions (Zimmerman et al. 1990, Minello \& Zimmerman 1991, Rozas 1993, Kneib \& Wagner 1994, McIvor \& Rozas 1996). Such variability should also be expected in the relative value of created marshes in relation to natural marshes. For example, the rate of sediment development in created marshes (based on organic content and benthic infaunal organisms), may be more rapid in Texas (Lindau \& Hossner
1981. Minello \& Zimmerman 1992) than on the Southeast Coast of the United States (Cammen 1975, Craft et al. 1988, Sacco 1989, Craft et al. 1991, LaSalle et al. 1991, Sacco et al. 1994).

Our study is based primarily on a comparison of animal densities among 5 natural and 10 created salt marshes. This use of animal densities is predicated on the assumption that density distributions reflect a habitat's value in providing essential functions for a species. Although we believe this paradigm is generally accepted (Rozas \& Minello 1997), it may not always be true. Measurements of animal growth and mortality within marshes would provide more direct information on. relative habitat value, but these measurements are difficult to obtain. Even obtaining density data for nekton within marshes has been a problem (Kushlan 1974 , Zimmerman et al. 1984, Kneib 1991, Rozas 1992, Rozas \& Minello 1997). We used an enclosure sampler to measure nekton densities on the marsh surface and in adjacent subtidal habitats. Similar quantitative sampling techniques seldom have been used to assess utilization of created marshes (Minello \& Zimmerman 1992, Meyer et al. 1993, Streever \& Crisman 1993 Minello et al. 1994). 
Table 5. Stepwise multiple regression analyses on log-transformed densities of abundant fauna collected in drop samples using 8 independent variabies; percent of time flooded over the year (FLOOD), sediment macro-organic matter (MOM), log-transformed abundance of sediment infauna (INF), sample water depth (DEPTH), salınity (SAL), water temperature (TEMP), dissolved oxygen (DO), and turbidity (TURB). The independent variable name is shown in italics if the relationship is negative Data for each season are from all samples on the marsh surface $(\mathrm{n}=57 \mathrm{in}$ fall and $47 \mathrm{in}$ spring). At each step of the analysis, the included variables are shown in order of their partial F-ratio in that model along with the adjusted $\mathrm{R}^{2}$ value for the model, ns indicates that none of the variables contributed significantly to a model

\begin{tabular}{|c|c|c|c|c|c|c|}
\hline \multirow[t]{2}{*}{ Dependent variable } & \multicolumn{6}{|c|}{ Independent variables } \\
\hline & Step 1 & $\mathrm{R}^{2}$ & Step 2 & $R^{2}$ & Final & $\mathrm{R}^{2}$ \\
\hline \multicolumn{7}{|l|}{ FALL } \\
\hline Total macrofauna & FLOOD & 0.43 & FLOOD MOM & 0.47 & FLOOD MOM DEPTH & 0.51 \\
\hline Fishes & DEPTH & 0.38 & DEPTH SAL & 0.43 & DEPTH SAL & 0.43 \\
\hline Gobiosoma bosc & DEPTH & 0.26 & DEPTH SAL & 0.42 & DEPTH SAL MOM & 0.47 \\
\hline Gobionellus boleosoma & DO & 0.23 & DO FLOOD & 0.27 & DO FLOOD & 0.27 \\
\hline Symphurus plagiusa & DEPTH & 0.29 & DEPTH TEMP & 0.34 & DEPTH TEMP & 0.34 \\
\hline Sciaenops occellatus & DEPTH & 0.18 & DEPTH SAL & 0.28 & DEPTH SAL & 0.28 \\
\hline Cynoscion nebulosus & DEPTH & 0.38 & & & & \\
\hline Decapod crustaceans & FLOOD & 0.44 & FLOOD MOM & 0.49 & FLOOD MOM DEPTH & 0.52 \\
\hline Palaemonetes pugio & FLOOD & 0.32 & & & & \\
\hline Penaeus setiferus & TURB & 0.28 & TURB DEPTH & 0.38 & TURB DEPTH INF & 0.42 \\
\hline Palaemonetes vulgaris & FLOOD & 0.22 & FLOOD SAL & 0.37 & FLOOD SAL & 0.37 \\
\hline Palaemonetes intermedius & $S A L$ & 0.26 & SAL FLOOD & 0.39 & SAL FLOOD & 0.39 \\
\hline Callinectes sapidus & FLOOD & 0.42 & FLOOD TURB & 0.46 & FLOOD TURB & 0.46 \\
\hline Clibanaruus vittatus & FLOOD & 0.14 & FLOOD DEPTH & 0.24 & FLOOD DEPTH TEMP & 0.36 \\
\hline Penaeus aztecus & TURB & 0.38 & TURB DEPTH & 0.46 & TURB DEPTH MOM DO INF & 0.60 \\
\hline \multicolumn{7}{|l|}{ Molluscs } \\
\hline Littoraria irrorata & as & & & & $n s$ & \\
\hline \multicolumn{7}{|l|}{ SPRING } \\
\hline Total macrofauna & $S A L$ & 0.18 & SAL DEPTH & 0.25 & DEPTH FLOOD & 0.35 \\
\hline Fishes & ns & ns & & & & \\
\hline Brevoortia patronus & DEPTH & 0.19 & DEPTH SAL & 0.25 & DEPTH SAL & 0.25 \\
\hline Lagodon rhomboides & DO & 0.55 & DO TURB & 0.60 & DO INF SAL TURB & 0.71 \\
\hline Decapod crustaceans & DEPTH & 0.14 & DEPTH FLOOD & 0.33 & DEPTH FLOOD TURB & 0.39 \\
\hline Palaemonetes pugro & ns & ns & & & & \\
\hline Penaeus aztecus & FLOOD & 0.27 & FLOOD TURB & 0.37 & FLOOD TURB DEPTH & 0.47 \\
\hline Callinectes sapidus & DEPTH & 0.33 & $D E P T H$ & 0.33 & & \\
\hline Clibanarius vittatus & DO & 0.26 & & & DO & 0.26 \\
\hline \multicolumn{7}{|l|}{ Molluscs } \\
\hline Littoraria irrorata & ns & & & & ns & \\
\hline
\end{tabular}

In general, densities of both fishes and decapod crustaceans were lower in created marshes than in natural marshes. Statistically significant differences were observed for fishes (mainly gobies and pinfish), marsh grass shrimp, brown shrimp, white shrimp, and blue crabs. Densities of commercially important decapods in created marshes were only 25 to $41 \%$ of the densities in natural marshes. Nekton densities were never significantly greater in created marshes than in natural marshes. These density results are similar to those observed by Minello \& Zimmerman (1992) for other natural and created ( 2 to $5 \mathrm{yr}$ of age) marshes on the Texas coast. The most abundant decapod crustacean, Palaemonetes pugio, the daggerblade grass shrimp, was found in similar numbers in natural and created marshes; but shrimp in created marshes were signifi- cantly smaller than those in natural marshes. We did not routinely record sex or stage of maturation in our analyses, but a re-examination of several samples suggested that the percentage of $P$. pugio that were gravid females was also lower in the created marshes.

The size and density differences observed for nekton may be due to inadequate food resources in created marshes (Moy \& Levin 1991, Shreffler et al. 1992). Macro-organic matter and populations of infaunal organisms in marsh sediments provide food for these fishes and decapods (Morgan 1980, Weisberg et al. 1981. Weisberg \& Lotrich 1982, Kneib 1985, 1986, Hunter \& Feller 1987. Thomas 1989, Rozas \& LaSalle 1990, Feller 1991, McTigue \& Zimmerman 1991. Minello \& Zimmerman 1991, McTigue 1993, Currin et al. 1995), and both MOM and infaunal densities 
Table 6. Mean densities (no. per $2.6 \mathrm{~m}^{2}$ drop sample) and standard errors of fishes and dominant crustaceans for natural marshes, low-elevation created marshes (T1, T3, T4, T5, T7, T10), and high-elevation created marshos (T2, T6, T8, T9). Only data from vegetated habitats (edge and inner marsh) were used in this analysis. Probability values are from contrasts in a 1-way ANOVA on In-transformed densities

\begin{tabular}{|c|c|c|c|c|c|}
\hline \multirow[t]{2}{*}{ Taxa } & \multirow{2}{*}{$\begin{array}{c}\text { Natural } \\
\text { Mean (SE) }\end{array}$} & \multirow{2}{*}{$\begin{array}{l}\text { Low created } \\
\text { Mean (SE) }\end{array}$} & \multirow{2}{*}{$\begin{array}{l}\text { High created } \\
\text { Mean (SE) }\end{array}$} & \multicolumn{2}{|c|}{ ANOVA contrast $p$-values } \\
\hline & & & & Nat vs Low & Nat vs High \\
\hline \multicolumn{6}{|l|}{ Fall } \\
\hline Fishes & $13.4(2.00)$ & $18.8(6.37)$ & $5.8(1.71)$ & 0.555 & 0.002 \\
\hline Crustaceans & $338.6(61.07)$ & $409.9(102.36)$ & $248.8(71.29)$ & 0.969 & 0.022 \\
\hline Palaemonetes pugio & $158.0(35.63)$ & $237.7(65.78)$ & $146.6(50.94)$ & 0.492 & 0.164 \\
\hline Penacus aztecus & $11.1(2.18)$ & $5.8(1.22)$ & $2.4(1.69)$ & 0.025 & 0.000 \\
\hline Penaeus setiferus & $69.5(24.46)$ & $54.2(22.15)$ & $12.9(5.76)$ & 0.259 & 0.000 \\
\hline Callinectes sapidus & $24.0(2.74)$ & $15.5(3.03)$ & $8.7(2.82)$ & 0.007 & 0.000 \\
\hline \multicolumn{6}{|l|}{ Spring } \\
\hline Fishes & $16.8(2.10)$ & $19.0(4.38)$ & $29.4(6.66)$ & 0.409 & 0.257 \\
\hline Crustaceans & $164.9(23.12)$ & $103.2(19.32)$ & $140.1(26.27)$ & 0.032 & 0.435 \\
\hline Palaemonetes pugio & $92.2(20.21)$ & $69.9(17.57)$ & $77.5(19.50)$ & 0.318 & 0.881 \\
\hline Penaeus aztecus & $51.1(9.78)$ & $16.3(2.35)$ & $7.4(2.19)$ & 0.002 & 0.000 \\
\hline Callinectes sapidus & $9.0(1.57)$ & $6.0(1.77)$ & $9.9(1.21)$ & 0.007 & 0.304 \\
\hline
\end{tabular}

(mainly the polychaete worm Streblospio benedicti) were significantly lower in our created salt marshes. There was little evidence for strong correlative relationships between these sediment parameters and densities of nekton on the marsh surface, but relationships between prey populations and predator abundance in marshes are complex (Kneib \& Stiven 1982. Kneib 1988, Minello \& Zimmerman 1992). Information currently being analyzed on benthic microalgae, meiofauna, sediment organic content, and infaunal productivity in these marshes may provide additional insights into nekton distribution patterns.

Perhaps the most defining characteristic of any wetland is its hydrology (Mitsch \& Gosselink 1986), and the hydrology of these shoreline Spartina alterniflora marshes is mainly determined by tidal flooding patterns. Tidal flooding of the 5 natural marshes was similar; elevations were consistently low and flooding durations were high. In contrast, tidal flooding patterns among the created marshes were highly variable. Hydrologic differences can affect marsh use and habitat value in several ways (Rozas 1995). High-elevation marshes that are infrequently flooded, such as some of the created marshes in this study, are simply not available for direct exploitation by nekton to the extent of lower elevation marshes. Even when the marshes are flooded and fully accessible, however, our data indicate that flooding patterns affect nekton use, as evidenced by strong positive relationships between annual flooding durations and densities of many decapod crustaceans. In an experimental study, Minello et al. (1994) identified distance to the marsh/water interface (edge) and elevation as important factors affecting nekton densities on the surface of Marsh T1 Edge effects should have been minimal in our study because no samples were farther than $5 \mathrm{~m}$ from the marsh/ water interface. Our data, however, support the importance of surface elevation in determining the use of near-edge habitats by nekton. Rozas \& Reed (1993) also documented differential use of marsh elevations by nekton in Louisiana; brown shrimp and white shrimp were concentrated in low-elevation marsh habitat.

When confronted with evidence of functional deficiencies in created wetlands, it commonly has been assumed that these wetlands will eventually develop into fully functioning habitats (Mitsch \& Wilson 1996). This assumption has instigated searches for the slope and shape of developmental trajectories (Kentula et al. 1992, Richardson 1994, Simenstad \& Thom 1996). Our created salt marshes ranged in age from 3 to $15 \mathrm{yr}$, thus we expected to see a general pattern of increased nekton use with marsh age. However, we found no obvious age-related patterns in use of the marshes by any nekton species examined. Sediment MOM increased with marsh age, but even this relationship was weak; age only explained $9 \%$ of the variability in MOM. These data may indicate that the time required to reach functional equivalency is very long, and trends cannot be observed within 15 yr. Or the data may indicate that some created salt marshes never reach functional equivalence with natural marshes (Sacco et al. 1994, Brinson \& Rheinhardt 1996, Simenstad \& Thom 1996). For nekton, we conclude that variability in use and in functional development rate is high in these created wetlands and that factors other than age are more important in determining habitat value. Marsh surface elevation appears to be a key characteristic influencing the value of created marshes for fishery species and estuarine nekton. Unless elevation changes occur 
in the temporal development of a marsh, it appears unlikely that high-elevation created marshes will ever reach functional equivalency with natural marshes for these organisms.

Acknowledgements. This research was funded by the Estuarine Habitat Program of NOAA's Coastal Ocean Program, the Southeast Fisheries Science Center of the National Marine Fisheries Service, and by Texas A\&M University at Galveston. We thank the large number of people that contributed through their efforts in collecting and processing samples; they include Marie Pattillo, T. Baumer, J. Christenson, M. Daniels, A. Goldberg, G. Gonzales, E. Higgins, S. Humphreys, E. Martinez, G. McMahan, B. Patterson, Mark Pattillo, J. Thomas, M. Van, A. Williams, and R. Wooten. Assistance with data analysis was provided by $T$. Baumer and $T$. Delaney. Water level data from the Pier 21 tide gauge was provided by NOAA's National Ocean Service. Earlier versions of the manuscript were vastly improved by encorporating review comments from $G$. Matthews, Marie Pattillo, L. Rozas, Z. Zein-Eldin, and 3 anonymous reviewers.

\section{LITERATURE CITED}

Baltz DM, Rakocinski C, Fleeger JW (1993) Microhabitat use by marsh-edge fishes in a Louisiana estuary. Environ Biol Fish 36:109-126

Brinson MM, Rheinhardt $\mathrm{R}$ (1996) The role of reference wetlands in functional assessment and mitigation. Ecol Appl 6:69-76

Broome SW (1989) Creation and restoration of tidal wetlands of the Southeastern United States. In: Kusler JA, Kentula $M E$ (ed) Wetland creation and restoration: the status of the science. Volume 1: Regional overviews. EPA/600/3-89/ 038. US Environ Prot Agency, Corvallis, p 37-72

Broome SW, Seneca ED, Woodhouse WW (1988) Tidal salt marsh restoration. Aquat Bot 32:1-22

Cammen LM (1975) Accumulation rate and turnover time of organic carbon in a salt marsh sediment. Limnol Oceanogr 20:1012-1015

Craft CB, Broome SW, Seneca ED (1988) Nitrogen, phosphorus and organic carbon pools in natural and transplanted marsh soils. Estuaries 11:272-280

Craft CB, Seneca ED, Broome SW (1991) Porewater chemistry of natural and created marsh soils. J Exp Mar Biol Ecol 152:187 200

Currin CA, Newell SY, Paerl HW (1.995) The role of standing dead Spartina alterniflora and benthic microalgae in salt marsh food webs: considerations based on multiple stable isotope analysis. Mar Ecol Prog Ser 121:99-116

Delaney TL (1994) A comparison of physical characteristics between transplanted and natural Spartina alterniflora marshes in lower Galveston Bay, Texas. MSc thesis, Texas A\&M University. College Station

Feller RJ (1991) Dietary analysis of penaeid shrimp: the immunoassay approach. In: DeLoach P, Dougherty WJ, Davidson MA (eds) Frontiers in shrimp research. Elsevier Sci Publ, Amsterdam, p 141-156

Havens KJ, Varnell LM, Bradshaw JG (1995) An assessment of ecological conditions in a constructed tidal marsh and two natural reference tidal marshes in coastal Virginia. Ecol Eng 4:117-141

Heck KL, Coen LD (1995) Predation and the abundance of blue crabs: a comparison of selected East and Gulf coast (USA) studies. Bull Mar Sci 57:877-883
Hunter J, Feller RJ (1987) Immunological dietary analysis of two penaeid shrimp species from a South Carolina tidal creek. J Exp Mar Biol Ecol 107:61.-70

Kentula M, Brooks R, Gwin S, Holland C, Sherman A, Sifneos $J$ (1992) An approach to improving decision making in wetland restoration and creation. U.S. Environmental Protection Agency; Pennsylvania State University Forest Resources Laboratory; ManTech Environmental Technology, Inc

Kneib RT (1985) Predation and disturbance by grass shrimp, Palaemonetes pugio Holthuis, in soft-substratum benthic invertebrate assemblages. J Exp Mar Biol Ecol 93:91-102

Kneib RT (1986) The role of Fundulus heterochtus in salt marsh trophic dynamics. Am Zool 26:259-69

Kneib RT (1988) Testing for indirect effects of predation in an intertidal soft-bottom community. Ecology 69:1795-1805

Kneıb RT (1991) Flume weir for quantitative collection of nekton from vegetated intertidal habitats. Mar Ecol Prog Ser $75: 29-38$

Kneib RT, Stiven AE (1982) Benthic invertebrate responses to size and density manipulations of the common mummichog, Fundulus heteroclitus, in. an intertidal salt marsh. Ecology 63:1518-1532

Kneib RT, Wagner SL (1994) Nekton use of vegetated marsh habitats at different stages of tidal inundation. Mar Ecol Prog Ser 106:227-238

Kushlan JA (1974) Quantitative sampling of fish populations in shallow freshwater environments. Trans Am Fish Soc 103:348-352

LaSalle MW, Landin MC. Sims JG (1991) Evaluation of the flora and fauna of a Spartina alterniflora marsh established on dredged matenal in Winyah Bay, South Carolina. Wetlands 11:191-208

Lindau CW, Hossner LR (1981) Substrate characterization of an experimental marsh and three natural marshes. Soil Sci Soc Am J 45:1171-76

Mclvor C, Rozas LP (1996) Direct use of intertidal saltmarsh habitat and linkage with adjacent habitats: a review from the southeastern United States. In: Nordstrom KF, Roman CT (eds) Estuarine shores: evolution, environments and human alterations. John Wiley \& Sons, New York, p 311-334

McTigue TA (1993) Trophic roles in juvenile Penaeus aztecus Ives and Penaeus setiferus (Linnaeus) in a Texas salt marsh. PhD dissertation, Texas A\&M University, College Station

McTigue TA, Zimmerman RJ (1991) Carnivory versus herbivory in juvenile Penaeus setiferus (Linnaeus) and Penaeus aztecus (Ives). J Exp Mar Biol Ecol 15:1-16

Meyer DL, Fonseca MS, Colby DR, Kenworthy WJ, Thayer GW (1993) An examination of created marsh and seagrass utilization by living marine resources. In: Magoon $\mathrm{O}$. Wilson WS, Converse H, Tobin LT (ed) Coastal Zone '93, Vol 2. Proceedings of the 8th Symposium on Coastal and Ocean Management. American Society of Civil Engineers, New York p 1858-1863

Minello TJ, Zimmerman RJ (1983) Fish predation on juvenile brown shrimp. Penaeus aztecus Ives: the effect of simulated Spartina structure on predation rates. J Exp Mar Biol Ecol 72:211-231

Minello TJ, Zimmerman RJ (1991) The role of estuarine habitats in regulating growth and survival of juvenile penaeld shrimp. In: DeLoach P. Dougherty WJ , Davidson MA (ed) Frontiers in shrimp research. Elsevier Sci Publ, Amsterdam, p 1-16

Minello TJ, Zimmerman RJ (1992) Utilization of natural and transplanted Texas salt marshes by fish and decapod crus- 
taceans. Mar Ecol Prog Ser 90:273-285

Minello TJ, Zimmerman RJ, Martinez EX (1989) Mortality of young brown shrimp Penaeus aztecus in estuarine nurseries. Trans Am Fish Soc 118:693-708

Minello TJ, Zimmerman RJ, Medina R (1994) The importance of edge for natant macrofauna in a created salt marsh Wetlands 14:184-198

Mitsch WJ, Gosselink JG (1986) Wetlands. Van Nostrand Reinhold, New York

Mitsch WJ, Wilson RF (1996) Improving the success of wetland creation and restoration with know-how, time, and self-design. Ecol Appl 6:77-83

Morgan MD (1980) Grazing and predation of the grass shrimp Palaemonetes pugio. Limnol Oceanogr 25:896-902

Moy LD, Levin LA (1991) Are Spartina marshes a replaceable resource? A functional approach to evaluation of marsh creation efforts. Estuaries 14:1-16

Peterson GW, Turner RE (1994) The value of salt marsh edge vs interior as a habitat for fish and decapod crustaceans in a Louisiana tidal marsh. Estuaries 17:235-262

Race MS, Christie DR (1982) Coastal zone development: mitigation, marsh creation, and decision-making. Environ Manag 6:317-328

Richardson CJ (1994) Ecological functions and human values in wetlands - a framework for assessing forestry impacts. Wetlands 14:1-9

Rozas LP (1992) Bottomless lift net for quantitatively sampling nekton in intertidal marshes. Mar Ecol Prog Ser 89: $287-292$

Rozas LP (1993) Nektor use of salt marshes of the Southeast region of the United States. In: Magoon O, Wilson WS, Converse H, Tobin LT (eds) Coastal Zone '93, Vol 2. Proceedings of the 8th Symposium on Coastal and Ocean Management. American Society of Civil Engineers, New York, p 528-537

Rozas LP (1995) Hydroperiod and its influence on nekton use of the salt marsh: a pulsing ecosystem. Estuaries 18: $579-590$

Rozas LP, LaSalle MW (1990) A comparison of the diets of gulf killifish, Fundulus grandis Baird and Girard, entering and leaving a Mississippi brackish marsh. Estuaries 13(3): $332-336$

Rozas LP, Minello TJ (1997) Estimating densities of small fishes and decapod crustaceans in shallow estuarine habitats: a review of sampling design with focus on gear selection. Estuaries 20:199-213

Rozas LP, Reed DJ (1993) Nekton use of marsh-surface habitats in Louisiana (USA) deltanc salt marshes undergoing submergence. Mar Ecol Prog Ser 96:147-157

Sacco J (1989) Infaunal community development of artificially established salt marshes in North Carolina. PhD dissertation, North Carolina State University, Raleigh

Sacco JN, Seneca ED, Wentworth TR (1994) Infaunal community development of artificially established salt marshes in North Carolina. Estuaries 17:489-500

This article was presented by G. W. Thayer (Semor Editorial Advisor), Beaufort, North Carolina, USA
Shreffler DK, Simenstad CA, Thom RM (1992) Foraging by juvenile salmon in a restored estuarine wetland. Estuaries $15: 204-213$

Simenstad CA, Thom RM (1996) Functional equivalency trajectories of the restored Gog-Le-Hi-Te estuarine wetland. Ecol Appl 6:38-56

Streever WJ, Crisman TL (1993) A comparison of fish populations from natural and constructed freshwater marshes in central Florida. J Freshwater Ecol 8:149-153

Thomas JL (1989) A comparative evaluation of Halodule wrightii Aschers, Spartina alterniflora Loisel and bare sand as nursery habitats for juvenile Callinectes sapidus (Rathbun). MSc thesis, Texas A\&M University, College Station

Thomas JL, Zimmerman RJ, Minello TJ (1990) Abundance patterns of juvenile blue crabs (Callinectes sapidus) in nursery habitats of two Texas bays. Bull Mar Sci 46: $115-125$

Turner RE (1977) Intertidal vegetation and commercial yields of penaeid shrimp. Trans Am Fish Soc 106:411-16

Webb JW, Newling CJ (1985) Comparison of natural and man-made salt marshes in Galveston Bay complex, Texas. Wetlands 4:75-86

Weisberg SB, Lotrich VA (1982) The importance of an infrequently flooded intertidal salt marsh surface as an energy source for the mummichog Fundulus heteroclitus: an experimental approach. Mar Biol 66:307-310

Weisberg SB, Whalen R, Lotrich VA (1981) Tidal and diurnal influence on food consumption of a salt marsh killifish Fundulus heteroclitus. Mar Biol 61:243-246

White WA, Tremblay TA (1995) Submergence of wetlands as a result of human-induced subsidence and faulting along the upper Texas Gulf coast. J Coastal Res 11:788-807

White WA, Tremblay TA, Wermund EG Jr, Handley LR (1993) Trends and status of wetland and aquatic habitats in the Galveston Bay system, Texas. The Galveston Bay National Estuary Program Publication GBNEP-31

Woodhouse WW, Seneca ED, Broome SW (1972) Marsh building with dredge spoil in North Carolina. North Carolina State University Agric Exp Stn Univ Bullut No. 445

Zedler JB (1993) Canopy architecture of natural and planted cordgrass marshes: selecting habitat evaluation criteria Ecol Appl 3:123-138

Zedler JB (1996) Ecological issues in wetland mitigation: an introduction to the forum. Ecol Appl 6:33-37

Zimmerman RJ, Minello TJ (1984) Densities of Penaeus aztecus, $P$. setiferus and other natant macrofauna in a Texas salt marsh. Estuaries 7:421-433

Zimmerman RJ, Minello TJ, Castiglione M, Smith D (1990) Utilization of marsh and associated habitats along a salinity gradient in Galveston Bay. NOAA Tech. Mem. NMFSSEFC-250

Zimmerman RJ, Minello TJ, Zamora G (1984) Selection of vegetated habitat by brown shrimp, Penaeus aztecus, in a Galveston Bay salt marsh. Fish Bull US 82:325-336

Manuscript first recelved: Aprl 30,1996

Revised version accepted: March 14, 1997 


\title{
ERRATUM
}

\section{Use of natural and created Spartina alterniflora salt marshes by fishery species and other aquatic fauna in Galveston Bay, Texas, USA}

\author{
Thomas J. Minello, James W. Webb, Jr
}

Mar Ecol Prog Ser 151: 165-179, 1997

- Table 5 on page 176 contained incorrect italicisation and misplaced entries. The corrected table appears below.

Table 5. Stepwise multiple regression analyses on log-transformed densities of abundant fauna collected in drop samples using 8 independent variables; percent of time flooded over the year (FLOOD), sediment macro-organic matter (MOM), log-transformed abundance of sediment infauna (INF), sample water depth (DEPTH), salinity (SAL), water temperature (TEMP), dissolved oxygen (DO), and turbidity (TURB). The independent variable name is shown in italics if the relationship is negative. Data for each season are from all samples on the marsh surface $(n=57$ in fall and 47 in spring). At each step of the analysis, the included variables are shown in order of their partial $F$-ratio in that model along with the adjusted $\mathrm{R}^{2}$ value for the model; ns indicates that none of the variables contributed significantly to a model

\begin{tabular}{|c|c|c|c|c|c|c|}
\hline \multirow[t]{2}{*}{ Dependent variable } & \multicolumn{6}{|c|}{ Independent variables } \\
\hline & Step 1 & $\mathrm{R}^{2}$ & Step 2 & $\mathrm{R}^{2}$ & Fina] & $\mathrm{R}^{2}$ \\
\hline \multicolumn{7}{|l|}{ FALL } \\
\hline Total macrofauna & FLOOD & 0.43 & FLOOD MOM & 0.47 & FLOOD MOM DEPTH & 0.51 \\
\hline Fishes & DEPTH & 0.38 & DEPTH $S A L$ & 0.43 & DEPTH SAL & 0.43 \\
\hline Gobiosoma bosc & DEPTH & 0.26 & DEPTH SAL & 0.42 & DEPTH SAL MOM & 0.47 \\
\hline Gobionellus boleosorna & $\mathrm{DO}$ & 0.23 & DO FLOOD & 0.27 & DO FLOOD & 0.27 \\
\hline Symphurus plagiusa & DEPTH & 0.29 & DEPTH TEMP & 0.34 & DEPTH TEMP & 0.34 \\
\hline Sciaenops occellatus & DEPTH & 0.18 & DIEPTH SAL & 0.28 & DEPTH SAL & 0.28 \\
\hline Cynoscion nebulosus & DEPTH & 0.38 & & & & \\
\hline Decapod crustaceans & FLOOD & 0.44 & FLOOD MOM & 0.49 & FLOOD MOM DEPTH & 0.52 \\
\hline Palaemonetes pugio & FLOOD & 0.32 & & & & \\
\hline Penaeus setiferus & TURB & 0.28 & TURB DEPTH & 0.38 & TURB DEPTH INF & 0.42 \\
\hline Palaemonetes vulgaris & FLOOD & 0.22 & FLOOD SAL & 0.37 & FLOOD $S A L$ & 0.37 \\
\hline Palaemonetes intermedius & $S A L$ & 0.26 & SAL FLOOD & 0.39 & SAL FLOOD & 0.39 \\
\hline Callinectes sapidus & FLOOD & 0.42 & FLOOD TURB & 0.46 & FLOOD TURB & 0.46 \\
\hline Clibanarius vittatus & FLOOD & 0.14 & FLOOD DEPTH & 0.24 & FLOOD DEPTH TEMP & 0.36 \\
\hline Penaeus aztecus & TURB & 0.38 & TURB DEPTH & 0.46 & TURB DEPTH MOM DO INF & 0.60 \\
\hline \multicolumn{7}{|l|}{ Molluscs } \\
\hline Littoraria irrorata & ns & & & & ns & \\
\hline \multicolumn{7}{|l|}{ SPRING } \\
\hline Total macrofauna & $S A L$ & 0.18 & SAL DEPTH & 0.25 & DEPTH FLOOD & 0.35 \\
\hline Fishes & ns & & & & ns & \\
\hline Brevoortia patronus & DEPTH & 0.19 & DEPTH SAL & 0.25 & DEPTH SAL & 0.25 \\
\hline Lagodon rhomboides & DO & 0.55 & DO TURB & 0.60 & DO INF SAL TURB & 0.71 \\
\hline Decapod crustaceans & DEPTH & 0.14 & DEPTH FLOOD & 0.33 & DEPTH FLOOD TURB & 0.39 \\
\hline Palaemonetes pugio & ns & & & & ns & \\
\hline Penaeus aztecus & FLOOD & 0.27 & FLOOD TURB & 0.37 & FLOOD TURB DEPTH & 0.47 \\
\hline Callinectes sapidus & DEPTH & 0.33 & & & $D E P T H$ & 0.33 \\
\hline Clibanarius vittatus & DO & 0.26 & & & DO & 0.26 \\
\hline \multicolumn{7}{|l|}{ Molluscs } \\
\hline Littoraria irrorata & ns & & & & ns & \\
\hline
\end{tabular}

